\title{
THE SUBCLAVIAN ARTERY AND ITS BRANCHES IN THE SMALL GREEN MONKEY (CERCOPITHECUS AETHIOPS SABEUS)
}

\author{
BLAGOJEVIĆ ZDENKA, BLAGOJEVIĆ M, NIKOLIĆ ZORA, DREKIĆ D, MRVIĆ VERICA, \\ ĐELIĆ DIJANA and ZORIĆ Z
}

Faculty of Veterinary Medicine, Belgrade

(Received 11. July 2004)

Within experimental, human and veterinary medicine, more and more attention has been paid to experimental animals. One of them being the small green monkey (Cercopithecus aethiops sabeus).

The small green monkey (Cercopithecus aethiops sabeus) has a short muzzle, small teeth, and is mostly of gray-greenish color; the lower part of its neck, chest, belly and inner sides of its thoracic limbs being whitish. Its total length is about $110 \mathrm{~cm}$, the tail being $50 \mathrm{~cm}$ long. On its head, on both sides, there are white hairs directed towards the neck, reminiscent of whiskers. The monkeys have large buccal sacs. The extremities and tail are more gray than the rest of the body. The skin of the face, ears and fore limbs is black. The digits are very long, whilst the thumb short.

Cell cultures from the small green monkey are used for the cultivation of poliovirus in the manufacture of vaccines against poliomyelitis. In addition, kidney cultures from the same monkey serve for detection of the virus in biological material. This was the main reason that prompted us to undertake a study of one part of the monkey's cardiosvascular system and thus contribute to a better understanding of the structure of its body.

Key words: Cercopithecus aethiops sabeus, subclavian artery.

\section{INTRODUCTION}

The small green monkey (Cercopithecus aethiops sabeus) belongs to the family of old-world monkeys (Radovanovic, 1965) widely distributed in African savannahs. The monkeys that we studied had been brought from Eastern Africa, i.e. Kenya, Uganda and Tanzania. They are considered to be the most beautiful and lovely monkeys. They can often be seen in zoos and are most frequently grey-green in colour except that the lower parts of the neck, chest, abdomen and inner side of the arms are white. According to existing data, mostly from zoos, they live for about 15-17 years, exceptionally 20 . They are fertile between 4 and 7 years of age.

The available literature offers very little information on the arteries in the small green monkey. Blagojevic et al., (2004) described arterial vascularization of 
the brain of the small green monkey (Cercopithecus aethiops sabeus). Nikolic et al. (2003) described the distribution of the left coronary artery branches in the African green monkey. Blagojevic et al. (1999, 1998, 1989) described the vascularization of the lungs, the internal artery and the heart arteries in the small green monkey (Cercopithecus aethiops sabeus). Teofilovski (1982) had presented earlier the insulopercular region of the brain of the small green monkey, Stanojevic et al. $(1982,1983)$ and Mrvic (1995) investigated the morphology of the genital organs. Hence the reason for studies of the subclavian artery and its branches in the small green monkey which were compared to the corresponding arteries in the dog (Bradley, 1948, Jankovic et al., 1988, Nickel et al., 1981, Baum and Ellenberger 1974), pig (Jankovic et al., 1988, Nickel et al., 1981, Baum et al., 1974) and man (Boskovic, 1971, Slivic, 1965) .

\section{MATERIALS AND METHODS}

The investigation involved 35 small green monkeys of both sexes, aged 3 to 4 years and body weight $2000-3000 \mathrm{~g}$. The monkeys originated from the Institute of immunology and virusology in Belgrade. After bleeding out, various contrast agents were introduced into the blood vessels. The most often used contrast media were: gelatin stained with painting tempera, micropack-barium and minium. Photographs of the blood vessels were taken after preparation.

Biocryl (a mixture of liquid biocryl-methyl-methacrylate monomer and powdered biocryl-methyl-methacrylate polymer), dyed with minium, was injected into the blood vessels in order to obtain corrosive preparations of the arteries. After initiation, the preparations were kept in $5 \% \mathrm{NaOH}$ for $96 \mathrm{~h}$ or in $10 \% \mathrm{NaOH}$ for $48 \mathrm{~h}$ after which the preparations were rinsed out with hot water.

\section{RESULTS AND DISCUSSION}

The A.subclavia is a paired blood vessel. The A. subclavia sinistra (Figure $1_{3}$, $2_{3}$ ) originates directly from the arch of the aorta and the $A$. subclavia dextra (Figure $1_{7}, 2_{7}, 3_{1}$ ) arises from the Truncus brachiocephalicus, fused into a common origin stem with the $A$. carotis communis dextra (Figure $1_{5}, 2_{5}$ ). Both the $A$. subclavia sinistra and dextra are blood vessels that vascularize the left and right thoracic limbs, the cranial part of the thorax and the caudal part of the neck. They run cranially, emerging at the thoracic entrance, then turn in a curve at the first rib to continue as the $A a$. axillares (Figure $2_{12,13}$ ). The $A$. subclavia gives the following branches:
1. A. vertebralis
2. A. scapularis dorsalis
3. A. thoracica interna
4. The common trunk for the $A$. cervicalis superficials and $A$. suprascapularis
5. Truncus costocervicalis 


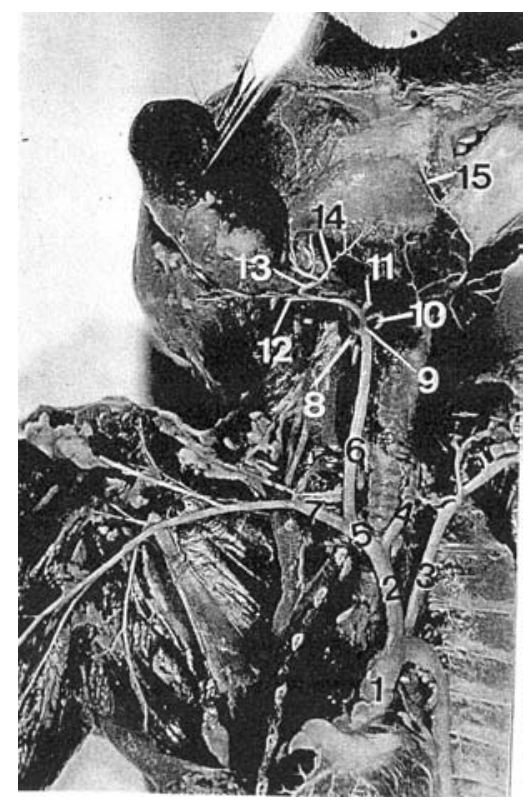

Figure 1. Arteries of the head of the small green monkey (Cercopithecus aethiops sabeus).

1- Aorta, 2- Truncus brachiocephalicus, 3- A. subclavia sinistra, 4- A. carotis communis sinistra, 5- The common trunk for the A. carotis communis dextra and A. subclavia dextra, 6- A. carotis communis dextra, 7- A. subclavia dextra, 8- A. carotis interna dextra, 9- A. carotis externa dextra, 10- A. pharyngea ascendens, 11- Truncus linguofacialis, 12- A. auricularis caudalis, 13- A. temporalis superficialis, 14- A. transversa faciei, 15- A. facialis.

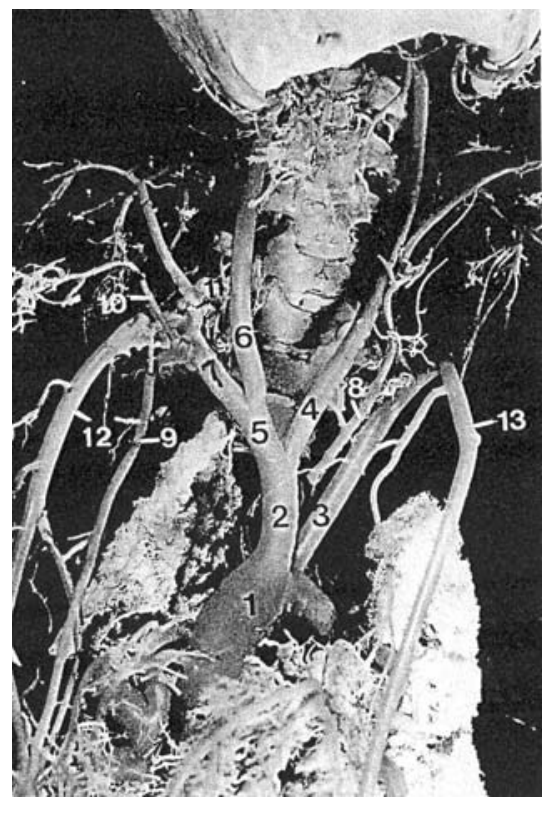

Figure 2. Arcus aortae of the small green monkey (Cercopithecus aethiops sabeus). The corrosive preparation.

1- Arcus aortae, 2- Truncus brachiocephalicus, 3- A. subclavia sinistra, 4- A. carotis communis sinistra, 5- The common trunk for the A. carotis communis dextra and A. subclavia dextra, 6A. carotis communis dextra, 7- A. subclavia dextra, 8- A. thoracica interna sinistra, 9- A. thoracica interna dextra, 10- A. scapularis dorsalis dextra, 11- The common trunk for the $A$. cervicalis superficialis and A. suprascapularis, 12- A. axillaris dextra, 13- A. axillaris sinistra.

\section{A. vertebralis}

A. vertebralis separates from $A$. subclavia in the thoracic cavity. It leaves the thorax at Apertura thoracis cranialis, and runs craniodorsally along the medial face of $M$. scalenus. At the sixth cranial vertebra it enters Canalis transversarius and passes through the canal up to the 2nd cranial vertebra where it ramifies, supplying branches for deep cranial muscles (Rami muscularis), as well as for the spinal cord (Rami spinales), by entering the spinal canal though intervertebral orifices. A. vertebralis leaves the transversal canal, enters Canalis transversarius atlas at the second cranial vertebra, and via Foramen vertebrale laterale enters the vertebral canal. Within the vertebral canal it perforates the dura and reaches the lateral side of the spinal cord. A. vertebralis enters the cranial cavity through Foramen magnum. 
A. vertebralis sinistra and $A$. vertebralis dextra (Figure $3_{2}$ ) unite behind the pons at Fossa postpontina and form the basilar artery ( $A$. basilaris cerebri). A. basilaris cerebri divides into two terminal branches Aa. cerebrales caudales that, together with the branches of the internal carotid arteries, form the arterial circle.

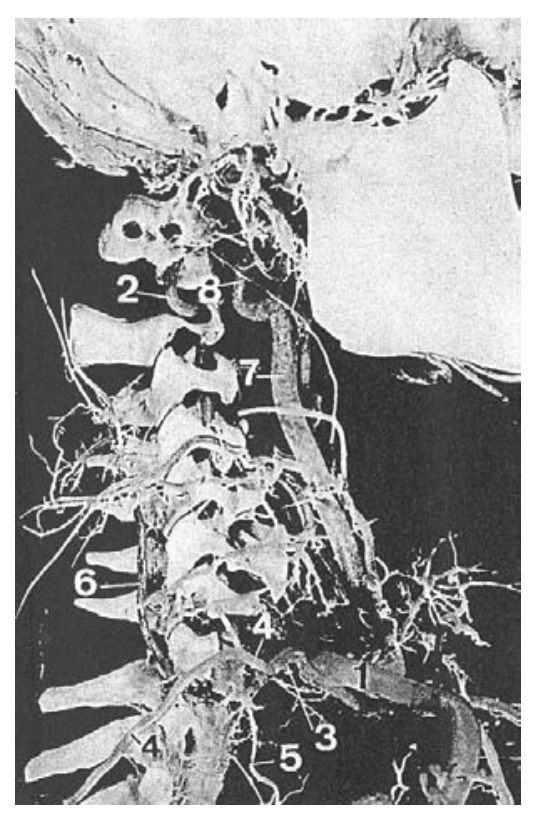

Figure 3. Arteries of the head and neck in the small green monkey (Cercopithecus aethiops sabeus). The corrosive preparation.

1- A. subclavia dextra, 2- A. vertebralis dextra, 3- Truncus costocervicalis, 4,4- A. transversa scapulae, 5- A. intercostalis suprema, 6- A. cervicalis profunda, 7- A. carotis communis dextra, 8- A. carotis interna dextra.

\section{A. scapularis dorsalis}

The A.scapularis dorsalis (Figure $2_{10}$ ) springs from the $A$. subclavia in the thoracic cavity. It leaves the thoracic cavity via the Apertura thoracis cranialis, turns in a curve caudally towards the dorsal angle of the scapula. It gives off branches for the vascularization of the $M$. serratus ventralis and the muscles and skin of the withers.

\section{A. thoracica interna}

The internal thoracic artery (A. thoracica interna, Figure 28,9 ) arises from

the $A$. subclavia in the thoracic cavity forming the common stem of origin for the $A$. cervicalis superficialis and $A$. suprascapularis.

It turns in a curve along the internal surface of the sternum towards its caudal part, giving off the Rami intercostales ventrales which anastomose with the 
terminal branches of the dorsal intercostal arteries (Aa. intercostales dorsales). The terminal branches of the internal thoracic artery are the A. musculophrenica and $A$. epigastrica cranialis.

4. The common trunk for $A$. cervicalis superficialis and $A$. suprascapularis

This trunk (Figure $2{ }_{11}$ ) separates from the $A$. subclavia at the same place as the $A$. thoracica interna, but proceeds opposite to the A. thoracica interna.

A. cervicalis superficialis

The $A$. cervicalis superficialis springs from the common stem of origin together with the A. suprascapularis. It gives off branches for vascularization of cranial muscles situated ventral to the trachea as well as for the lymph nodes of this part of the neck.

\section{A. suprascapularis}

The $A$. suprascapularis leaves the $A$. subclavia in the thoracic cavity originating from the common trunk together with the $A$. cervicalis superficialis. It runs dorsally towards the dorsal border of the scapula and passes between the $M$. subscapularis and $M$. supraspinatus. Its branches take part in the vascularization of muscles adjacent to the collar bone, shoulder joint, i.e to the muscles of the proximal part of the collar bone.

\section{Truncus costocervicalis}

The Truncus costocervicalis (Figure $3_{3}$ ) is a common stem of origin for the following blood vessels:

a) A. intercostalis suprema

b) $A$. cervicalis profunda

c) A. transversa scapulae

a) A. intercostalis suprema

The $A$. intercostalis suprema (Figure $3_{5}$ ) runs along the vertebral column and lateral part of the M. longus colli. It gives off the two first intercostal arteries.

b) A. cervicalis profunda

The A. cervicalis profunda (Figure $3_{6}$ ) arises from the costocervical trunk in a form of a common stem together with the $A$. transversa scapulae. It leaves the thoracic cavity at the Apertura thoracis cranialis, runs dorso-cranially towards the cranial part of the neck, giving off branches for deeper layers of cranial muscles.

c) A. transversa scapulae

The $A$. transversa scapulae (Figure $3_{4,4}$ ) arises, together with the $A$. cervicalis profunda, from the costocervical trunk in a form of a common trunk. It continues laterally towards the dorsal inner angle of the scapula. It ramifies into:

1. Ramus descendens

2. A. cervicalis ascendens. muscles.

The Ramus descendens runs caudally and vascularizes the thoracic 
The A.cervicalis descendens runs cranially towards the neck and vascularizes the musculature of that part of the neck.

There are variations in the ramification of the Truncus costocervicalis. In some cases, the Truncus costocervicalis gives off:

1. A.transversa scapulae

2. A. cervicalis profunda, that further gives off the A. intercostalis suprema; and in other cases:

\section{A. transversa scapulae}

2. A. intercostalis suprema

3. A. cervicalis profunda.

The $A$. subclavia sinistra in the small green monkey is similar as in man (Boskovic, 1971; Slivic, 1965), pig and dog (Nickel et al., 1981; Baum and Ellenberger, 1974; Jankovic et al.,1988) and arises directly from the arch of the aorta, and the $A$. subclava dextra, similar as in man, together with the $A$. carrotis communis, leaves the Truncus brachiocephalicus in a form of a common trunk. Both the $A$. subclavia sinistra and $A$. subclavia dextra run cranially, emerging at the front thoracic entrance, and turn in a curve around the first rib.

Branches of the $A$. subclavia, in the small green monkey, as in man (Boskovic, 1971; Slivic, 1965), are the A. vertebralis, A. scapularis dorsalis, $A$. thoracica interna and Truncus costocervicalis. In the monkey, the A. subclavia gives off also the common trunk for the $A$. cervicalis superficialis and $A$. suprascupularis; whereas, in man, it gives off the Truncus thyreocervicalis, too.

In the small green monkey, as in man (Boskovic, 1971; Slivic,1965), the Truncus costocervicalis branches into the $A$. intercostalis suprema and $A$. cervicalis profunda and $A$. transversa scapulae (the last one only in the small green monkey).

\section{ACKNOWLEDGEMENTS:}

These studies were supported by the Serbian Ministry of Science, Technology and Development, Grant No 1843. "Morphology of organs of experimental animals, small green monkey and their reactivity to hormones".

Address for correspondence:

Dr Blagojević Zdenka

Faculty of Veterinary Medicine, Department of Anatomy

Bulevar JNA 18,

11000 Belgrade, Serbia\&Montenegro

e-mail: zblagojevic@vet.bg.ac.yu

\section{REFERENCES}

1. Baum H, Ellenberger W, 1974, Handbuch der vergleichenden Anatomie der Haustiere,18, Auflage, Springer-Verlag, Berlin.

2. Blagojević Z, Nikolić Z, Đelić D, Mrvić V, Drekić D, Zorić Z, Blagojević M, 2004, Arterial vascularization of the brain of the small green monkey (Cercopithecus aethiops sabeus), Acta Vet Belgrade, 54, 319-24.

3. Blagojević Z, Mrvić V, 2000, Morfologija, topografija i arterijska vaskularizacija organa malog zelenog majmuna (Cercopithecus aethiops sabeus), Beograd. 
4. Blagojević Z, Mrvić V, Jovanović S, 1999, The vascularization of the lungs in the small green monkey (Cercopithecus aethiops sabeus), Acta Vet Belgrade, 49, 393-7.

5. Blagojević Z, Mrvić V, Jovanović S, Nikolić Z, 1998, The internal artery of the small green monkey (Cercopithecus aethiops sabeus), Acta Vet Belgrade, 48, 185-90.

6. Blagojević Z,1989, Srce i arterije malog zelenog majmuna (Cercopithecus aethiops sabeus), Doktorska disertacija, FVM Beograd.

7. Bošković M, 1971, Anatomija čoveka, VII izd., Medicinska knjiga, Beograd.

8. Bradley OC, 1948, Topographical anatomy of the dog, Edinburgh-London.

9. Ilić A, Bogdanović D, Jeličić N, 1973, O načinu odvajanja prvih pobočnih grana spoljne karotidne arterije, Srpski arhiv za celokupno lekarstvo, poseban otisak, 101, 2, 117, Beograd.

10. Janković Ž, Stanojević D, Miladinović Ž, 1988, Anatomija domaćih životinja sisara, Angiologia, Beograd.

11. Mrvić V, 1995, Morfologija, topografija i vaskularizacija ženskih polnih organa malog zelenog majmuna (Cercopithecus aethiops sabeus), Doktorska disertacija, FVM Beograd.

12. Nickel R, Schummer A, Seiferle E, 1981, The Anatomy of the Domestic Animals. The circulatory system, the skin, and the cutaneous organs of the domestic mammals, 3, Verlag Paul Parey, Berlin, Hamburg.

13. Nikolić V, Blagojević Z, Malobabić S, Aranđelović A, Mališ M, Teofilovski-Parapid G, Stanković I, 2003, Distribution of the left coronary artery branches in the African green monkey, Acta Vet Belgrade, 53,139-50.

14. Radovanović M, 1965, Zoologija, drugi deo. Sistematika životinja, Naučna knjiga, Beograd.

15. Stanojević D, Teofilovski G, Bogdanović D, 1981, Arteries at the base of the brain of Cercopithecus sabeus, Acta anatomica, III / 1-2, 35.

16. Stanojević D, Drekić D, Blagojević Z, Nikolić Z, 1983, Muški genitalni organi majmuna Cercopithecus aethiops sabeus (testis, epididimys, ductus deferens), Folia anatomica lugoslavica, 13, 83-91, Sarajevo.

17. Stanojević D, Nikolić Z, Blagojević Z, 1982, The female genital organs in the Cercopithecus aethiops sabeus, Abstracts, XIV Kongres udruženja anatoma Evrope, Berlin.

18. Šljivić B, 1965, Sistematska i topografska anatomija (glava i vrat sa čulnim organima) II izdanje, dopunjeno i prerađeno, Medicinska knjiga, Beograd-Zagreb.

19. Teofilovski G, Stanojević D, Bogdanović D, 1984, Arterije baze mozga Cercopithecus aethiops sabeus, Medicinska istraživanja, časopis Medicinskog fakulteta Univerziteta u Beogradu, 17, sv. 1-2.

20. Teofilovski G, 1982, Anatomska istraživanja inzuloopekularnog regiona, Doktorska disertacija, Medicinski fakultet Beograd.

\section{ARTERIJA SUBKLAVIA I NJENE GRANE U MALOG ZELENOG MAJMUNA (CERCOPITHECUS AETHIOPS SABEUS)}

\section{BLAGOJEVIĆ ZDENKA, BLAGOJEVIĆ M, NIKOLIĆ ZORA, DREKIĆ D, MRVIĆ VERICA, ĐELIĆ DIJANA i ZORIĆ Z}

\section{SADRŽAJ}

A. subclavia sinistra malog zelenog majmuna se direktno odvaja od luka aorte, a $A$. subclavia dextra se odvaja od Truncus brachiocephalicus-a zajedničkim stablom sa $A$. carotis communis dextra.

A. subclavia sinistra et dextra su krvni sudovi koji vaskularišu levi i desni prednji ekstremitet, prednji deo grudnog koša i kaudalni deo vrata. 
Od A. subclavia odvajaju se: $A$. vertebralis, $A$. scapularis dorsalis, $A$. thoracica interna, zajedničko stablo za $A$. cervicalis superficialis i $A$. suprascapularis i Truncus costocervicalis.

A. vertebralis i $A$. carotis interna su glavni krvni sudovi koji dovode arterijsku krv u mozak. $A$. vertebralis daje grane za duboke vratne mišiće (rami musculares), kao i grane za kičmenu moždinu (rami spinales). Spajanjem leve i desne kičmene arterije ( $A$. vertebralis sinistra et dextra) nastaje $A$. basilaris cerebri.

A. scapularis dorsalis daje grane za vaskularizaciju $M$. serratus ventralis i za mišiće i kožu grebena leđa.

A. thoracica interna daje rami intercostales ventrales koji anastomoziraju sa završnim granama dorzalnih međurebarnih arterija (Aa. intercostales dorsales).

Zajedničko stablo za $A$. cervicalis superficialis i $A$. suprascapularis se odvaja na istom mestu od $A$. subclavia gde i $A$. thoracica interna, ali se pruža na suprotnu stranu od $A$. thoracica interna.

A. cervicalis superficialis daje grane za vaskularizaciju mišića vrata koji leže ventralno od dušnika i za limfne čvorove ovog dela vrata.

A. suprascapularis vaskulariše mišiće proksimalnog dela ramenjače.

Truncus costocervicalis je zajedničko stablo za $A$. intercostalis suprema, $A$. cervicalis profunda i $A$. transversa scapulae. 